Elmaraghy, A., Voordijk, H., and Marzouk, M. (2018). "An exploration of BIM and Lean interaction in optimizing demolition projects." In: Proc. $26^{\text {th }}$ Annual Conference of the International. Group for Lean Construction (IGLC), González, V.A. (ed.), Chennai, India, pp. 112-122. DOI: doi.org/10.24928/2018/0474. Available at: www.iglc.net

\title{
AN EXPLORATION OF BIM AND LEAN INTERACTION IN OPTIMIZING DEMOLITION PROJECTS
}

\author{
Ahmed Elmaraghy ${ }^{1}$, Hans Voordijk ${ }^{2}$, and Mohamed Marzouk ${ }^{3}$
}

\begin{abstract}
Construction and demolition wastes have an adverse environmental impact. The demolition wastes are resulted from the linear economic behaviour that the Construction industry is currently adopting. IT-enabled processes like BIM have been used to eliminate wastes in Construction Projects. The alignment of these processes with Lean Construction principles was seen to reap high benefits. This research investigates the possibility of extending BIM functionalities to support deconstruction processes in alignment with Lean Principles. Based on the existing interaction matrix between BIM functionalities and Lean Principles and its subsequent extensions, the synergies between BIM and Lean are explored from a deconstruction perspective. The evidence of using BIM capabilities in deconstruction projects is mainly interpreted from research in addition to the current initiatives in the demolition and renovation projects in The Netherlands. The main aim is to integrate discrete efforts in industry and academia towards leveraging the recovery rate of salvaged elements. The evidence is then validated against Lean principles and the results reveal a major conformity between BIM and Lean. This exploratory research may contribute to the adoption of a structured framework in deconstruction projects that exploits BIM and Lean capabilities towards achieving a circular economy.
\end{abstract}

\section{KEYWORDS}

Lean construction, Building Information Modelling (BIM), Pull, Deconstruction, Waste.

\section{INTRODUCTION}

Construction industry is the major contributor to the overall waste streams generated worldwide (Wang et al. 2010). For instance 25 to $30 \%$ of all the wastes generated in EU

1 MSc Student, Integrated Engineering Design and Management Program (IEDM), Faculty of Engineering, Cairo University, +20 102222 6978, ahmedelmaraghy92@gmail.com

2 Associate Professor of Supply Chain Management, Department of Construction Management and Engineering, Twente University, The Netherlands, + 3153489 4214, jtvoordijk@utwente.nl

3 Professor of Construction Engineering and Management, Structural Engineering Department, Faculty of Engineering, Cairo University, Egypt, +20 2 35678425, mm_marzouk@yahoo.com 
is owed to construction and demolition waste (C\&D) (European Commission 2016). The current practice of buildings demolition undergoes a linear economic approach. Large portions of wastes are generated and less amounts of salvaged materials are being recovered and pumped back into the supply chain (Hosseini et al. 2014). In recent years, IT-based processes like Building Information Modelling (BIM) was introduced in deconstruction projects. The exploitation of BIM capabilities has taken many forms including the development of BIM-based deconstruction plug-ins (Akbarnezhad et al. 2014), and the visualisation of the 4D deconstruction scheduling (Ge et al. 2017).

On the other hand, there are insights in literature that shows the implicit reliance on lean principles in planning the deconstruction projects. These principles promote pulling data from downstream instead of the traditional push approach. This can be done by selecting the building elements to be dismantled based on the end-customers' needs, thus engaging them in the early decision making. In this context, (Schultmann and Rentz 2002) proposed that the nearest manufacturing typology that best suits deconstruction processes is 'Make to Order' production. This means that the process relies on applying just-in-time concepts where the presence of inventory is minimal. In addition, 'Make to Order' means that the production line will capture the production signal only when a demand exists on a certain product.

However, highlighting the potential of Lean-BIM interaction was merely mentioned in deconstruction projects. In fact, most of the researches that exploit the effect of BIMLean integration in reducing the amounts of Construction and demolition wastes (C\&D) are focused on wastes generated during the construction phase only. For instance, (Cheng et al. 2015) has investigated the use of BIM functionalities in enabling the waste minimization in construction processes. Among these functionalities were design validation, quantity take-off, phase planning and site utilization planning. Therefore, the perspective of optimizing demolition and deconstruction processes haven't yet been explored within a Lean-BIM interaction perspective.

\section{LEAN-BIM INTERACTION MATRIX}

In order to capture the synergies between Lean Principles and BIM functionalities, (Sacks et al. 2010) have provided a framework for analysing these interactions. They were arranged in a matrix, where each BIM functionality is analysed against each Lean Principle. The result can be positive, which indicates a full compliance to the indicated Lean Principle, or negative, where the BIM functionality opposes in its implementation the Lean Principle.

This framework is regarded suitable for exploratory research where the conformity between 2 processes need to be identified. This constructive approach was also extended and built upon by other researchers in phases like the operation and maintenance (Oskouie et al. 2012). Accordingly, this research extends the use of Lean-BIM matrix to capture the conformity patterns between Lean and BIM in deconstruction and demolition projects. 


\section{EXTENDED LEAN PRINCIPLES}

For the selection of the principles, some criteria have been used. First, the production control approach adopted by Pull-planning has been a key-issue in choosing the relevant principles. Second, the criteria provided in (Sacks et al. 2010) for the development of the Lean Principles have been used. However, some modifications were done, besides the addition of more concepts to account for the variations between construction and deconstruction processes (see Table 1). Lean principles were classified into 2 main categories: strategic management and operational planning. As for the strategic management-related aspects, they fall under 4 sub-categories: the decision making, transparency, value creation and developing partners. While the operational planning is divided into 2 sub-categories: inspection and flow of the process. The synergies between these principles and BIM functionalities can be inferred from the explanations of each interaction in the matrix.

Table 1: Lean Principles

\begin{tabular}{|c|c|c|}
\hline \multicolumn{2}{|l|}{ Lean Principle } & \multirow{2}{*}{$\begin{array}{l}\text { Key } \\
\text { A }\end{array}$} \\
\hline & Planning the decision-making structure early in the process & \\
\hline $\begin{array}{l}\text { making } \\
\text { process }\end{array}$ & The early involvement of the stakeholders in the process & B \\
\hline \multicolumn{2}{|c|}{ Consider all options } & C \\
\hline \multicolumn{2}{|c|}{ Processes must be more transparent with decentralized decision making } & D \\
\hline \multicolumn{2}{|c|}{ Careful selection of technology that reaps high value to the end-customer } & $\mathrm{E}$ \\
\hline \multicolumn{2}{|c|}{ Ensure Comprehensive requirements capture } & $\mathrm{F}$ \\
\hline \multicolumn{2}{|c|}{ Focus on Concept Selection } & G \\
\hline \multicolumn{2}{|c|}{ Ensure Requirements Flow-down } & $\mathrm{H}$ \\
\hline \multicolumn{2}{|c|}{ Verify and Validate } & I \\
\hline \multicolumn{2}{|c|}{ Cultivate an extended network of partners } & $\mathrm{J}$ \\
\hline \multicolumn{2}{|c|}{ Go and see for yourself } & K \\
\hline \multirow{3}{*}{$\begin{array}{l}\text { Pull from } \\
\text { Downstream }\end{array}$} & Project planning is based on the end-customer needs & L \\
\hline & $\begin{array}{l}\text { Minimize inventories of goods awaiting further processing by levelling the } \\
\text { production }\end{array}$ & M \\
\hline & Resource management based on production flow & $\mathrm{N}$ \\
\hline $\begin{array}{l}\text { Reduce } \\
\text { Variability }\end{array}$ & $\begin{array}{l}\text { Creating a smooth workflow by removing variations in workloads (one-piece } \\
\text { flow) } \\
\text { Getting Quality right at the first time and reducing defects in products }\end{array}$ & $\begin{array}{l}\mathrm{O} \\
\mathrm{P}\end{array}$ \\
\hline \multicolumn{2}{|c|}{ Reduce cycle time } & Q \\
\hline \multicolumn{2}{|c|}{ Collaboration } & $\mathrm{R}$ \\
\hline Flexibility & & $\mathrm{S}$ \\
\hline \multirow{3}{*}{$\begin{array}{l}\text { Standardizing } \\
\text { the Process }\end{array}$} & Finding simplicity even within complex projects & $\mathrm{T}$ \\
\hline & $\begin{array}{l}\text { Structuring of the work to separate the standard activities from those relying } \\
\text { on the information change }\end{array}$ & $\mathrm{U}$ \\
\hline & Using Visual Management & $\mathrm{V}$ \\
\hline \multicolumn{2}{|c|}{ Institute Continuous Improvement } & W \\
\hline
\end{tabular}




\section{EXTENDED BIM FUNCTIONALITIES THAT SUPPORT DECONSTRUCTION PROCESSES}

BIM Functionalities mentioned in this context were retrieved from literature involved in deconstruction planning and from innovative practices in the Demolition projects in the Netherlands. These functionalities were classified based on the processes they are contributing to. There are possible extensions to these functionalities that can be added later. However, the main concern was to integrate the current discrete approaches that have been already adopted. The integration of more functionalities and testing their reliability can be expected in future work. Table 2 shows each BIM functionality included in the study and the key representing each one in the matrix table.

Table 2: BIM Functionalities

\begin{tabular}{ll}
\hline BIM Functionality & Key \\
\hline $\begin{array}{l}\text { Data Capturing } \\
\text { Digital documentation of buildings through laser scanning and photogrammetry }\end{array}$ & 1 \\
Modelling & 2 \\
$\quad$ Rapid generation of the BIM model & 3 \\
Visualization of the BIM model & 4 \\
Integrity of information provided in the model & 5 \\
Collaboration & 6 \\
$\quad$ Collaboration provided among stakeholders through BIM platforms & 7 \\
$\quad$ Collaboration in the modelling environment & \\
Interoperability & 8 \\
Object-based Programming & 9 \\
Manual input of deconstruction-related parameters & 10 \\
Importing data from external libraries and creating new parameters of them & \\
Re-use of model data for predictive analysis & 11 \\
Exporting model data to external plug-ins & 12 \\
Rapid evaluation and Simulation of Deconstruction Alternatives & 13 \\
Simulating the Schedule scenarios & 14 \\
Detecting the clashes (resulting from dismantling an element) & \\
The quantification of elements and materials to be dismantled & 15 \\
Automatic Generation of Reports & 16 \\
Online/Electronic based Communication & 17 \\
Updating the Deconstruction progress on-site & \\
Visualizing the dismantling process on-site & \\
Synchronizing BIM models with online applications & \\
\hline
\end{tabular}

\section{CASE STUDY}

Moondriaan Building is a facility that used to be a Care Center for people with needs in Heerlen in The Netherlands. The building was abandoned for several years and was decided to be demolished. Resource Limburg was hired to take care of demolishing the building. The vision was to undergo the process of deconstruction for elements that have re-use potential and then demolish the rest of the building and sent the materials to the recycling facilities. Resource Limburg also has a role in marketing the salvaged elements. 
This is done either through contacting the extended network of partners or showcasing the elements on their web shop (Resource Limburg 2017). Therefore, Resource Limburg can also be regarded as a consultant to the owner for guiding the deconstruction process.

The workflow of the process starts with the capturing the data on different building elements. The company has used laser scanning technology and panoramic 360 images to digitally document the building conditions. These conditions were evaluated by the Company's architects and experts. The evaluation is then formulated into linguistic terms that determine the quality of each element. The elements and their conditions are then
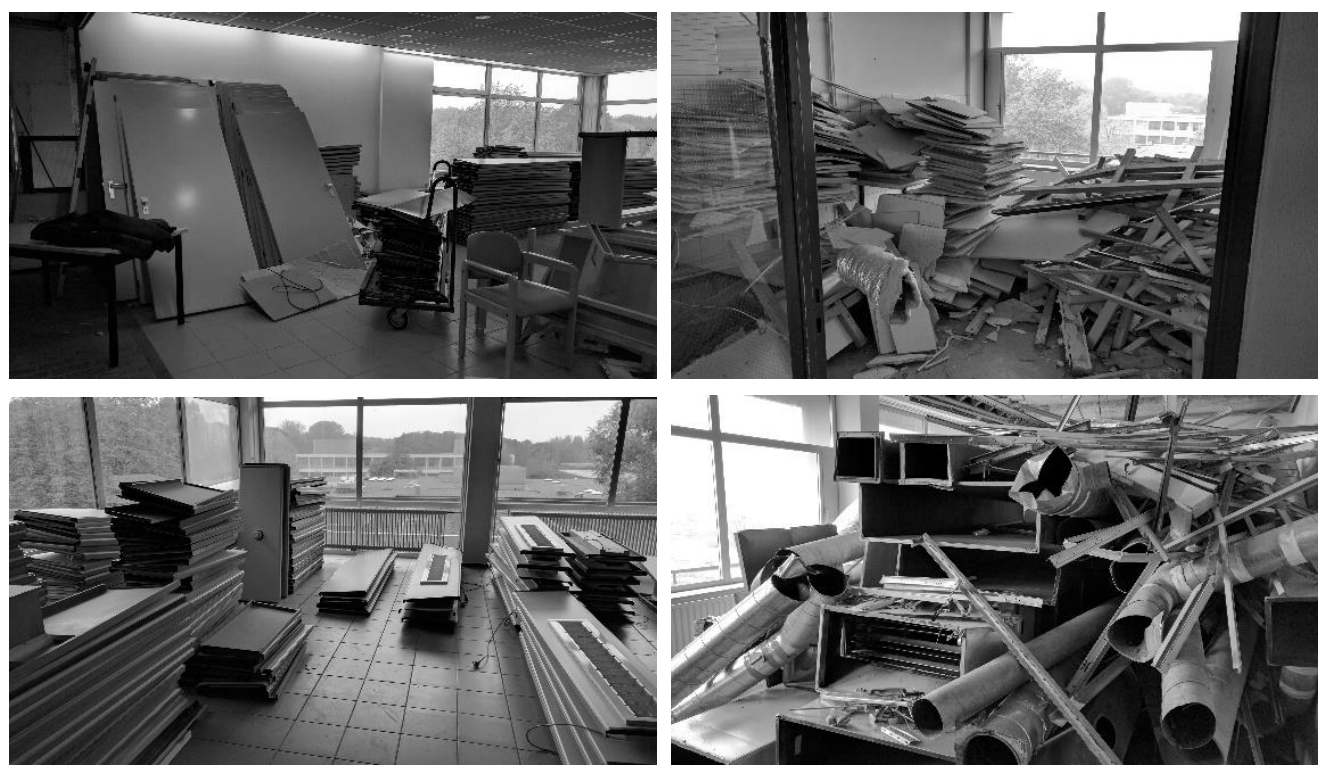

Figure 1: Different Collections of Salvage Elements stored inside the Building updated to a database. On site, elements are dismantled and stored on separate places inside the building (see Figure 1). Nearby customers, whom the company had relations with and who were interested in obtaining the salvaged elements, were invited to the site. In addition, the elements on the database were showcased on the Web-shop.

\section{DISCUSSION}

The need to detect the conformity of Lean Principles and BIM functionalities in deconstruction processes is explored using the Lean-BIM interaction matrix derived from (Sacks et al. 2010) as listed in Table 3. In this matrix, several interactions were noticed. These interactions are susceptible for further enhancements, extensions and verifications in future research. Hence, they can be regarded as an exploratory foundation for more structured demolition practices. Most of the interactions are a collection of discrete efforts in research and practice in optimizing deconstruction planning. Table 4 shows the explanation for each interaction in the matrix. For brevity reasons, the interactions, of which evidence was found in construction projects only, were marked by ' $\mathrm{X}$ ' and were not explained. These interactions are mostly applicable to deconstruction projects and can be inferred from evidence provided in (Sacks et al. 2010). There were also few 
interactions that had no available evidence, yet, they have been proposed by the authors. These interactions are regarded to be of possible potential in deconstruction projects.

Consequently, the mentioned interactions in Table 4 are mostly derived from both literature and practice. As for practice examples, they were mainly obtained from case studies in the Dutch construction industry. They represent an initiative, by social enterprises active in the construction sector, to adopt a more circular economic behaviour in demolition projects. This is done by introducing BIM technologies. It was found out that Lean principles were implicitly adopted in some of the pilot projects involved. 


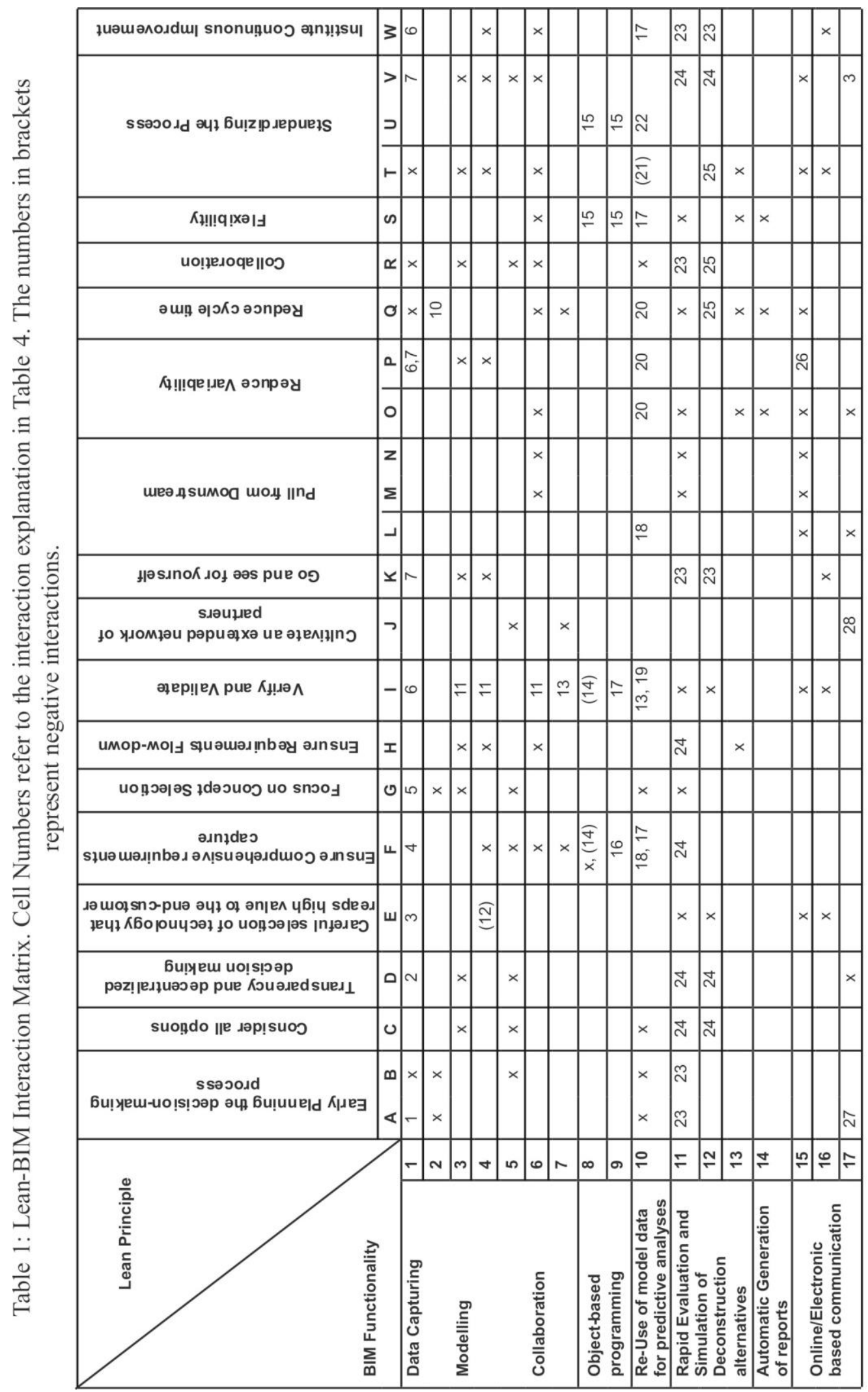


Table 3: Interaction Matrix: Explanations of Cell Contents

\begin{tabular}{|c|c|c|}
\hline Index & Explanation & Evidence \\
\hline 1 & $\begin{array}{l}\text { The current scanning processes which captures the building data, are quick } \\
\text { and efficient. Once the spatial data is collected on-site, the decisions on the } \\
\text { building deconstruction can be planned sufficient time before actual } \\
\text { demolition activities take place. }\end{array}$ & $\begin{array}{l}\text { (Ge et al. 2017; } \\
\text { Resource } \\
\text { Limburg 2017) }\end{array}$ \\
\hline 2 & $\begin{array}{l}\text { Visualization of the actual building conditions through digital documentation } \\
\text { is a transparent process. Instead of written reports, witnessing the current } \\
\text { building conditions contribute to a transparent decision-making process. }\end{array}$ & $\begin{array}{l}\text { (Resource } \\
\text { Limburg 2017) }\end{array}$ \\
\hline 3 & $\begin{array}{l}\text { Using the state-of-the-art scanning technologies reap the highest values to } \\
\text { the end-customer. The end-customer can visualize the panoramic, 3D point } \\
\text { cloud, or } 360 \text { images of the salvaged building elements captured. }\end{array}$ & $\begin{array}{l}\text { (Resource } \\
\text { Limburg 2017) }\end{array}$ \\
\hline 4 & $\begin{array}{l}\text { Point cloud data ensures capturing of comprehensive data-sets. This } \\
\text { gigantic amount of data (Big Data) carries accurate details of the building } \\
\text { elements condition. }\end{array}$ & $\begin{array}{l}\text { (Böhler and } \\
\text { Marbs 2004) }\end{array}$ \\
\hline 5 & $\begin{array}{l}\text { Careful Consideration and evaluation of preliminary alternatives is } \\
\text { supported by the presence of a digitally documented model of the project. }\end{array}$ & $\begin{array}{l}\text { (Resource } \\
\text { Limburg 2017) }\end{array}$ \\
\hline 6 & $\begin{array}{l}\text { Through the digital documentation of the initial building conditions, validating } \\
\text { the quality of the dismantling processes can be achieved. This is done by } \\
\text { comparing the salvaged element conditions after being dismantled with the } \\
\text { initial conditions that was digitally documented in the beginning of the } \\
\text { project. }\end{array}$ & $\begin{array}{l}\text { Not yet } \\
\text { available }\end{array}$ \\
\hline 7 & $\begin{array}{l}\text { Visualization of the building digital documentation ensures the detection of } \\
\text { defects of the building elements through visual inspection }\end{array}$ & $\begin{array}{l}\text { (Resource } \\
\text { Limburg 2017) }\end{array}$ \\
\hline 10 & $\begin{array}{l}\text { The rapid generation of the As-Built model for the salvaged buildings saves } \\
\text { more time for the next sequential processes in the planning of the building } \\
\text { deconstruction }\end{array}$ & $\begin{array}{l}\text { Not yet } \\
\text { available }\end{array}$ \\
\hline 11 & $\begin{array}{l}\text { Through the visualization of BIM objects representing the elements to be } \\
\text { salvaged and the surrounding objects on the BIM model, the deconstruction } \\
\text { sequence of such elements can be verified and the possibility to dismantle } \\
\text { them is validated. The same for clash detection that ensures the model } \\
\text { integrity. }\end{array}$ & $\begin{array}{l}\text { Not Yet } \\
\text { Available }\end{array}$ \\
\hline (12) & $\begin{array}{l}\text { BIM provides a set of tools and capabilities that are way more efficient than } \\
2 D \text { CAD drawings. Model integration and detecting discrepancies between } \\
\text { BIM objects is one of them. However, the full potential of model integration } \\
\text { is hindered by the loss of some data and the difficulty to explicitly detect the } \\
\text { relationships between different BIM objects based on certain criteria. }\end{array}$ & $\begin{array}{l}\text { (Ali and } \\
\text { Mohamed 2017) }\end{array}$ \\
\hline 13 & $\begin{array}{l}\text { Interoperability encourages the migration of data to external applications for } \\
\text { validation and/or analysis. }\end{array}$ & $\begin{array}{l}\text { (Pazlar and } \\
\text { Turk 2008) }\end{array}$ \\
\hline (14) & $\begin{array}{l}\text { The manual entry of data increases the probability of having errors. } \\
\text { Therefore, analyzing these data may yield unreliable outcomes. Additionally, } \\
\text { it's difficult to validate or verify them. }\end{array}$ & $\begin{array}{l}\text { (Alanjari et al. } \\
\text { 2015) }\end{array}$ \\
\hline 15 & $\begin{array}{l}\text { Attaching parameters to BIM objects can be done either using manual entry } \\
\text { of values or importing data from external libraries. Thus, there is flexibility in } \\
\text { the addition of parameters independent of the source type. }\end{array}$ & $\begin{array}{l}\text { (Akbarnezhad } \\
\text { et al. 2014) }\end{array}$ \\
\hline
\end{tabular}




\begin{tabular}{|c|c|}
\hline Index & Explanation \\
\hline 16 & $\begin{array}{l}\text { BIM follows an object-oriented approach in creating the hierarchy of BIM } \\
\text { objects. Therefore, this process provides possibility of defining new } \\
\text { parameters and linking them to the BIM objects. Adding parameters can } \\
\text { capture comprehensive data about different criteria. Parameters can bring } \\
\text { additional information to the model about the connectivity of the BIM objects } \\
\text { or the location of nearest recycling facilities...etc. }\end{array}$ \\
\hline 17 & $\begin{array}{l}\text { Verification of parameter values added to a BIM model can be achieved. By } \\
\text { developing a plug-in that can be added to the BIM authoring tool, different } \\
\text { parameters can be retrieved and analyzed. }\end{array}$ \\
\hline 18 & $\begin{array}{l}\text { Due to the early evaluation of building elements recovery potential by } \\
\text { analyzing BIM objects data, the quality of the end-product is increased and } \\
\text { becomes more consistent with the client needs (buyers of the salvaged } \\
\text { elements). }\end{array}$ \\
\hline 19 & $\begin{array}{l}\text { Exporting model data to external applications validates these data against } \\
\text { rules and regulations. It also verifies the suitability of the element conditions } \\
\text { for deconstruct ability. Some applications extend their scope to predict the } \\
\text { transportation costs, logistics, and the relevant impact on the environment } \\
\text { for the salvaged elements }\end{array}$ \\
\hline
\end{tabular}

20 Predicting the recovery potential of the building elements, represented by the BIM objects, ensures that the salvaged elements with high re-use potential can be identified and dismantled. Thus, variability resulting from the uncertainty of the element conditions is reduced. This helps in preserving the quality of these elements during the deconstruction process. In addition, it saves the time needed on-site to evaluate the building elements.

(21) Detailed predictive analysis and the generation of multiple parameters to be added to the model could increase the complexity of the model. This would hinder the easy extraction of information from the BIM model

22 Through the use of the BIM objects data in an external application, an analysis can be done to separate the elements with high recovery potential from the rest of the elements with no recovery potential.

23 Using BIM collaboration tools, it's possible to for multi-disciplinary teams to work together early in the project to create different scenarios for the deconstruction strategies using BIM collaboration platforms. These platforms support the visualization of deconstruction processes with the progress of the project, the dismantling sequence and the mobilization of salvaged elements. This environment leverages the decision making based on the selection of the most appropriate deconstruction strategy.

$244 \mathrm{D}$ scheduling presents a visualization of the deconstruction sequencing with the progress of the schedule. This is used to identify conflicts in time, space and assessing the deconstructability of salvaged elements. Safety, and efficiency of production is enabled, and production flow can be tracked and improved.

25 Simulating the path of the dismantled elements out of the building is enabled through BIM Collaboration tools. This ensures an accurate dismantling process on-site and saving time by virtually evaluating different scenarios before settling on the optimum one.

26 The visualization of deconstruction steps on a BIM model on-site (using rugged devices) reduces the error of dismantling an element and ensures its proper dismantling to preserve its condition.

\section{Evidence}

(Akbarnezhad

et al. 2014;

Krijnen and

Tamke 2015)

(Akbarnezhad

et al. 2014)

(Akbarnezhad

et al. 2014)

(Akbarnezhad

et al. 2014)

(Akbarnezhad et al. 2014; Eastman et al. 2011)

(Alanjari et al. 2015)

(Akinade et al. 2017)

(Eastman et al. 2011; Ge et al. 2017)

(Eastman et al. 2011; Ge et al. 2017)

(Autodesk

University 2013)

Not yet available 


\begin{tabular}{lll}
\hline Index & Explanation & Evidence \\
\hline 27 & A Web shop can be an example of the external applications supported by & (Resource \\
& BIM processes. This web-shop can show the data attached to BIM objects & Limburg 2017) \\
which represents the salvaged building elements in real world. The & \\
& elements sold on the Web shop can then by synchronized with the BIM & \\
& model for efficient deconstruction planning. Based on the demand of & \\
& building elements, the stakeholders can take early decisions on the destiny & \\
& of the salvaged elements and materials. & \\
28 & $\begin{array}{l}\text { Integration of different stakeholders involved in the recovery and re-use of } \\
\text { salvaged elements through online portals can create long term relationships } \\
\text { between them. It can also be regarded as an initiative for adopting circular }\end{array}$ & \\
& economy in construction practices. &
\end{tabular}

\section{CONCLUSION}

This paper extended the BIM-Lean interaction matrix to cover the deconstruction and demolition processes. The synopsis of interactions was supported by evidence from literature and practice. The interpretation of the matrix interactions could be directed towards the adoption of a BIM-Lean approach in future deconstruction projects. For example, the exploitation of BIM related technologies can be used to apply the lean principles in the context of showcasing the salvaged elements on a Web-Shop. This platform can be linked to the BIM model for updating the deconstruction scheduling. Finally, this exploratory research can yield, in the future work, a generic framework for the planning of deconstruction projects both on the strategic and operational level.

\section{REFERENCES}

Akbarnezhad, A., Ong, K. C. G., and Chandra, L. R. (2014). "Economic and environmental assessment of deconstruction strategies using building information modeling." Automation in Construction, 37, 131-144.

Akinade, O. O., Oyedele, L. O., Omoteso, K., Ajayi, S. O., Bilal, M., Owolabi, H. A., Alaka, H. A., Ayris, L., and Henry Looney, J. (2017). "BIM-based deconstruction tool: Towards essential functionalities." International Journal of Sustainable Built Environment, 6(1), 260-271.

Alanjari, P., RazaviAlavi, S., and AbouRizk, S. (2015). "Hybrid genetic algorithmsimulation optimization method for proactively planning layout of material yard laydown." Journal of Construction Engineering and Management, 141(10), 06015001.

Ali, M., and Mohamed, Y. (2017). "A method for clustering unlabeled BIM objects using entropy and TF-IDF with RDF encoding." Advanced Engineering Informatics, 33(Supplement C), 154-163.

Autodesk University (2013). "RC2261: Laser Scanning Gone Wild: 4D Clash Detection with the Point Cloud." <http://aucache.autodesk.com/au2013/sessionsFiles/2261/607/handout_2261_RC2261 .pdf>. (17 Nov, 2017). 
Böhler, W., and Marbs, A. "3D scanning and photogrammetry for heritage recording: a comparison." Proc., Proceedings of the 12th International Conference on Geoinformatics, Gavle University Press, Sweden, 291-298.

Cheng, J. C. P., Won, J., and Das, M. "Construction and Demolition Waste Management Using BIM Technology." Proc., 23rd Annual Conference of the International Group for Lean Construction, 381-390.

Eastman, C. M., Eastman, C., Teicholz, P., and Sacks, R. (2011). BIM handbook: A guide to building information modeling for owners, managers, designers, engineers and contractors, John Wiley \& Sons.

European Commission (2016). "European Commission - Environment - Construction and Demolition Waste

<http://ec.europa.eu/environment/waste/construction_demolition.htm

(CDW)."

$>$. (12 Jan, 2018).

Ge, X. J., Livesey, P., Wang, J., Huang, S., He, X., and Zhang, C. (2017). "Deconstruction waste management through $3 \mathrm{~d}$ reconstruction and bim: a case study." Visualization in Engineering, 5(1), 13.

Hosseini, M. R., Chileshe, N., Rameezdeen, R., and Lehmann, S. (2014). "Reverse logistics for the construction industry: Lessons from the manufacturing context." International Journal of Construction Engineering and Management, 3(3), 75-90.

Krijnen, T., and Tamke, M. (2015). Assessing Implicit Knowledge in BIM Models with Machine Learning.

Oskouie, P., Gerber, D. J., Alves, T., and Becerik-Gerber, B. "Extending the Interaction of Building Information modeling and lean construction." Proc., 20th Annual Conference of the International Group for Lean Construction.

Pazlar, T., and Turk, Ž. (2008). "Interoperability in practice: geometric data exchance using the IFC standard." Journal of Information Technology in Construction (ITcon), 13(24), 362-380.

Resource Limburg (2017). "Resource Limburg Web Shop." $<\mathrm{http}: / /$ www.resourcelimburg.nl/>. (4 Jan, 2018).

Sacks, R., Koskela, L., Dave, B. A., and Owen, R. (2010). "Interaction of lean and building information modeling in construction." Journal of construction engineering and management, 136(9), 968-980.

Schultmann, F., and Rentz, O. (2002). "Scheduling of deconstruction projects under resource constraints." Construction Management and Economics, 20(5), 391-401.

Wang, J., Yuan, H., Kang, X., and Lu, W. (2010). "Critical success factors for on-site sorting of construction waste: A china study." Resources, Conservation and Recycling, 54(11), 931-936. 